UDC 582.675.1 + $61+615.1$

DOI: $10.15587 / 2519-4852.2020 .201616$

\title{
CALTHA PALUSTRIS. ANALYTICAL OVERVIEW
}

\author{
V. Liakh, R. Konechna, A. Mylyanych, L. Zhurakhivska, I. Hubytska, V. Novikov
}

\begin{abstract}
Мета. Аналіз та узагальнення даних щзодо ареалу, вмісту біологічно активних сполук та спектру використання у фармації та медицині Caltha palustris.

Матеріали та методи. Літературні та електронні джерела інформаџіï, щзо стосуються поширення, хімічного складу та фармакологічної активності Caltha palustris.

Результати. Caltha palustris - багаторічна трав'яниста рослина з родини Жовтецевих (Ranunculaceae).. Рослина неофіцинальна, широко застосовується народною медициною як протизапальний, спазмолітичний, бактерицидний, протимікробний, болезаспокійливий, діуретичний засіб. Основними біологічно активними речовинами Caltha palustris є: дубильні речовини, глікозиди (ү-лактони протоанемонін та анемонін ) сапоніни, берберин, гіркоти, вітамін C, холін, каротин, флавоноїди та алкалоїди. Caltha palustris відносять до регіонально рідкісних рослин адміністративних територій Украӥни . 3 огляду на актуальність розширення асортименту лікарської рослинної сировини для створення сучасних лікувальних засобів та хімічний склад, фармакологічну дію Caltha palustris, дочільним є проведення подальших ресурсознавчих, фітохімічних та інших досліджень рослини.

Висновки. Враховуючи значний досвід застосування в народній медицині, иирокий спектр фармакологічної активності, вміст иінних біологічно активних сполук Caltha palustris є перспективною та иінною сировиною для одержання та виробництва фітохімічних препаратів та впровадження їх у практичне застосування
\end{abstract}

Ключові слова: Ranunculaceae, Caltha palustris, протоанемонін, анемонін, біологічно активні речовини, фармакологічна дія

Copyright $($ C 2020, V. Liakh, R. Konechna, A. Mylyanych, L. Zhurakhivska, I. Hubytska, V. Novikov. This is an open access article under the CC BY license (http://creativecommons.org/licenses/by/4.0).

\section{Introduction}

Today, the world pharmaceutical industry is making extensive use of herbal raw materials, which are the basis for the creation of medicines. A large number of drugs that are manufactured worldwide have natural ingredients of plant origin. Therefore, the search for new species of plants that could be a source of biologically active compounds, such as flavonoids, coumarins, hydroxycoric acids, alkaloids, saponins, amino acids and so on. There is some evidence to support the efficacy of herbal medicines in the treatment of a number of serious diseases. One of these is representatives of the Ranunculaceae family, since they are a source of biologically active compounds that have long been used in traditional medicine as a medicine with various pharmacological effects. One such representative is Caltha palustris. The plant is used for a long period in folk medicine of different countries and exhibits a wide range of medicinal properties.

Phytochemical and pharmacological studies of Caltha palustris have been partially conducted by separate groups of scientists in different fields.

Scientists from the University of British Columbia and Indian scientists from the Central Research Institute of Medicines conducted research on the content of triterpene [1-3]. In addition, German scientists from Bayreuth University [4] conducted the content of biologically active compounds in some representatives of the Ranun- culaceae family. Researchers from the Wroclaw University of Natural Sciences (Poland) conducted studies on the separation of polysaccharide fraction from Caltha palustris raw material [5]. Italian scientists from Ferraris University [6] carried out the identification of protoanemonin in the plant.

A group of Indian scientists from Kashmir University [7] carried out pharmacological action, including the determination of anthelmintic, antimicrobial, antioxidant and cytotoxic activity.

Polish scientists study the effect of polysaccharide fractions isolated from Caltha palustris on phagocytic cell activity and humoral immune responses in mice with induced arthritis [5, 8].

Caltha palustris has not been sufficiently studied at the present stage of the development of pharmaceutical science, so comprehensive studies of its raw materials are relevant.

The purpose of the research is to analyse and summarize the literature on the distribution, chemical composition of Caltha palustris and the features of its use for further pharmacognostic, phytochemical and pharmacological studies.

\section{Planning (methodology) of research}

For this purpose, the following problems must be solved: 
- Analyse current literary sources for data on the distribution of Caltha palustris in Ukraine;

- Summarize the literature on the content of biologically active compounds of Caltha palustris;

- To analyse and establish the possibilities and peculiarities of the use of Caltha palustris in pharmacy and medicine.

\section{Materials and methods}

Literary and electronic sources of information regarding the distribution, chemical composition and pharmacological activity of Caltha palustris were selected.

\section{Results of the research}

Caltha palustris (Fig. 1, 2) is a plant belonging to the family Ranunculaceae, a subclass of Ranunculidae. The Latin name of the genus Ranunculaceae is derived from the ancient Roman language. The species name in Latin means swamp [9].

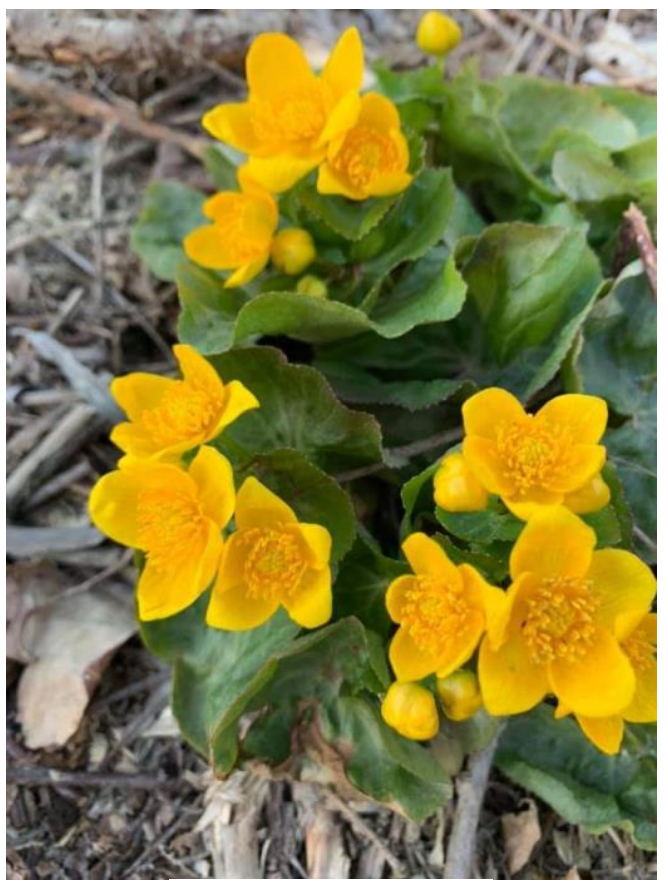

Fig. 1. Caltha palustris

\section{Botanical description.}

It is herbaceous plant with erect, simple or top branching stems, up to $20-50 \mathrm{~cm}$ in height. Leaves petiolate, entire, kidney- or heart-shaped, serrated toothed, dark green, shiny. Root leaves much larger than the stem ones. The flowers are $2-3 \mathrm{~cm}$ in diameter. Perianth simple, corolla of five, rarely - many petals. Petals oval or ovoid, golden yellow colour [10].

Stamens numerous, free. Pestle from 2 to 12. Fruit - aggregate.

The plant blooms in April and May. The first flowering of the plant begins only at the 10th year of its life. Leaf fruits containing up to 10 black shiny seeds that fall out after ripening in May and July.

Propagated by seeds and rhizomes [11, 12]. androgynous.

Formula of flower - ${ }^{*} \mathrm{Ca}_{5} \mathrm{Co}_{5} \mathrm{~A}_{\infty} \mathrm{G}_{(2-12)}$. Flower is

The number of chromosomes $2 \mathrm{n}=32$ and 56 [13].

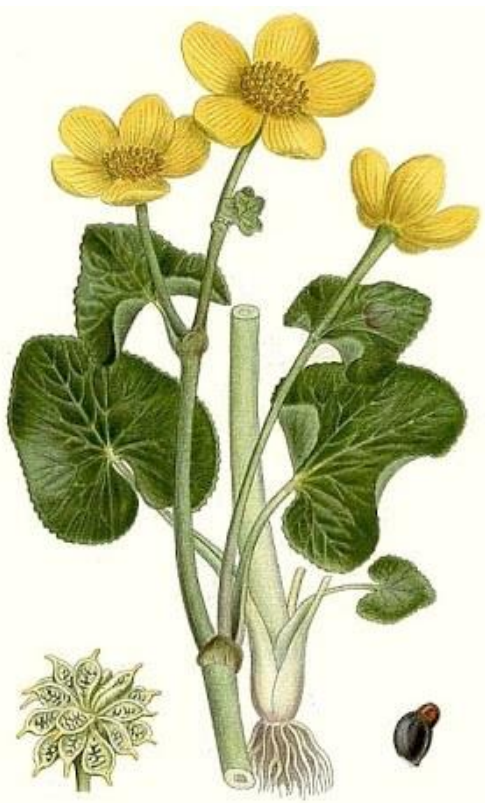

Fig. 2. Caltha palustris

Distribution and harvesting.

Caltha palustris is common in the Ukrainian Carpathians in all highlands.

It grows on the banks of ponds, wet meadows, lakes, wetlands, swamps, along rivers in slow flowing and stagnant waters, near wet channels $[14,15]$. The distribution map in Ukraine is presented in Fig. 3 [16].

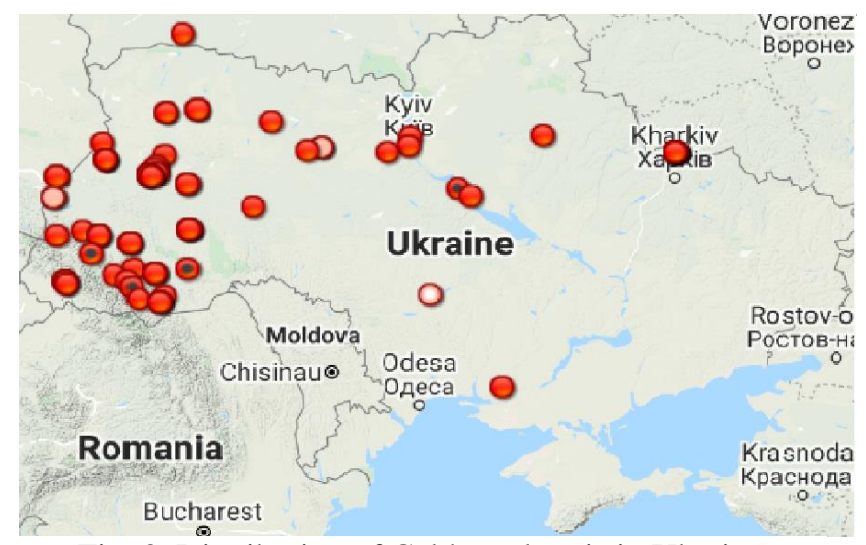

Fig. 3. Distribution of Caltha palustris in Ukraine

From the end of the sixteenth century, the plant began to grow in the gardens of Austria and southern Germany. It has become a valuable garden plant in the collections of connoisseurs of Austria, Switzerland, Germany, England, and Holland [17].

In Ukraine, it has long been used for medicinal purposes. They used all the aboveground part of the plant, which is harvested in the spring during flowering. They are dried in dark and well-ventilated areas, often turning over raw materials. It can be dried in ovens at $50-60{ }^{\circ} \mathrm{C}$.

The roots are harvested in the autumn, washed, crushed, decayed and dried in a dryer.

Shelf life (in pouches or wooden containers) is 12 years [18] 


\section{Chemical composition.}

Caltha palustris contains biologically active substances both primary and secondary synthesis. It consists of alkaloids, saponins, $\gamma$-lactones: protoanemonin, anemonin, tannins (8.1\%), ascorbic acid (37 mg \%) $[19,20]$.

All parts of the plant contain triterpenoids (palustrolide, caltolide, epicaltolide, 16,17-dihydroxycauronic-19 and hedrogenic acids), steroids (sitosterol), carotenoids (3-epilutein), coumarins (scopoletin, umbelliferone).

Heterocyclic geleborin compounds have been found in underground organs. The flowers contain flavonoids campferol, quercetin, 7-rhamnoside, 3-glucoside and 3-glucoside-7-rhamnoside of campferol, 7-rhamnoside, 3-glucoside, 3-glucoside-7-rhamnoside quercetin.

In the Caltha palustris grass, 16 connected phenolic structures have been identified: phenolic acids caffeic, chlorogenic, gallic, chicory, isochlorogenic, ferulic and flavonoids - apigenin, apigenin-3glycoside, luteolin-7-glycoside, k-glycoside; as well as catechin, epicatechin, epigallocatechin gallate and coumarin. The predominant among phenolic acids are chicory and gallic acids, and the flavonoids are dominated by apigenin [21].

Caltha palustris flowers contain pigments of trolixanthin, xanthophyll, epoxanthine, alloxanthine, seeds - fatty oil $(30 \%)$. Caltosides (glycosides of hederagenin and oleanolic acid), which have androgenic properties, have been found in the rhizomes and roots of Caltha palustris, which grows in the Far East [22].

The seeds have alkaloids, oils and vitamin C.

Due to the presence of a toxic substance protoanemonin the plant is poisonous, but after drying the toxic properties are lost because protoanemonin is converted into anemonin [15, 23].

The content of protoanemonin in the plant is relatively low compared to other members of the Ranunculaceae family $-0.26 \mathrm{p} . \mathrm{g} / \mathrm{g}$ fro wt. Protoanemonin is a metabolite of stress and serves to protect members of the Ranunculaceae family from external stimuli, so its number may vary [24].

Protoanemonin (Fig. 4) is a volatile, viscous, colourless oily substance with a pungent odour and a burning taste.

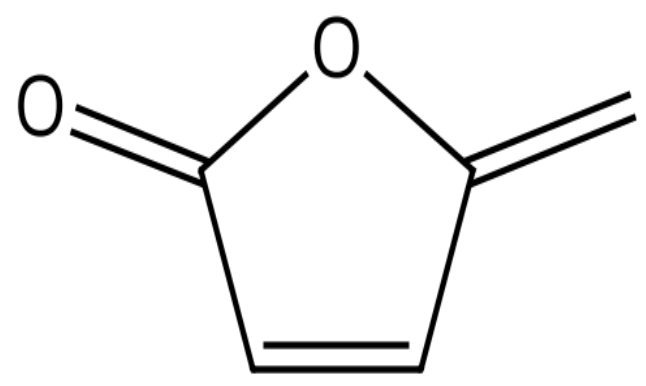

Fig. 4. Protoanemonin

By chemical nature belongs to the group of lactones. With long-term storage of aqueous solutions, the protoanemonic polymerizes and precipitates as crystalline anemonin. The beneficial effect of protoanemonin is manifested in a stimulating effect on the body: it tones the nervous system, improves haematopoiesis is of great importance In the treatment of purulent wounds and ulcers, as it exhibits antibiotic properties. Actively acts against gram-positive and acid-resistant bacteria [25].

Anemonin (Fig. 5) is found in many members of the Ranunculaceae family, from which it is obtained by distillation of the herbaceous parts. In the processing of chloroform distillation and evaporation of the chloroform solution, there are two crystalline substances: anemone camphor, which has very poisonous properties, quickly turns into amorphous anemonic acid, and anemonin. The latter is a rhombic crystals, melts at $156^{\circ} \mathrm{C}$, difficult to dissolve in hot water and ethers, easily - in hot alcohol and chloroform. Anemonin is poisonous; its ethereal solution in contact with the eyes leads to dilation of the pupils. However, it has analgesic and antispasmodic properties and is used in asthma, whooping cough, rickets and others [26].

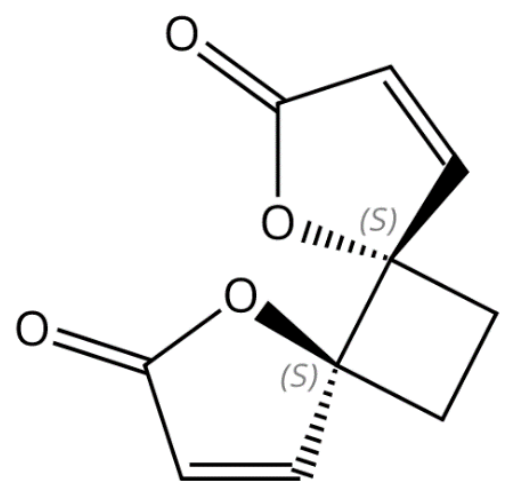

Fig. 5. Anemonin

Pharmacological action and use in medicine.

Caltha palustris is an unofficial plant. meopathy.

Caltha palustris is used in folk medicine and ho-

In folk medicine of Ukraine, Caltha palustris is most commonly used externally as an anti-inflammatory and analgesic agent for burns, wounds, bruises, rheumatism, neurodermatitis, eczema, etc. [27].

In small doses decoction or infusion of Caltha palustris grass is used internally for feverish conditions, whooping cough, bronchitis, asthma, metabolic disorders, diathesis, anemia, scurvy, painful menstruation and uterine carcinoma [28].

In Tibetan medicine they used infusion of flowers for the treatment of ascites.

In homeopathy, a plant is used to treat bronchitis and cough, menstrual disorders, and others. Homeopathic anti-cough drug is made from fresh flowering plants $[9,28]$.

\section{Dosage forms.}

On the domestic pharmaceutical market there are preparations containing Caltha palustris. These list include the complex homeotic drug Helium-Hel, which is made in the form of drops for oral use by the German company Biologische Heilmittel Heel Gmb H.

The drug has immunomodulatory, antiinflammatory, detoxification and drainage action, which is based on the activation of the body's defences 
and normalization of impaired functions due to substances of plant, mineral and animal origin, which are part of the drug.

The tool is used for chronic diseases that are often exacerbated; infections that require stimulation of nonspecific immunity; after the consequences of the toxic effects of drug therapy (antibiotics, chemotherapy, radiotherapy) [29].

The American company WHP (Washington Homeopatic Products), founded in 1873 under the name Washington Homeopathic Pharmacy, offers onecomponent homeopathic remedies from Caltha palustris. This company manufactures and markets its own homeopathic remedies and products manufactured by other companies in the world. Caltha palustris preparations are available in the form of tablets, granules and pills [30].

External:

- Decoction from the whole plant of the Caltha palustris. $1 / 2$ teaspoon of crushed dried raw material is poured into a glass of boiling water, simmered for 5 minutes on low heat and cooled for 1 hour, then filtered. Burned areas of the skin are washed with this decoction.

- Juice from fresh leaves and flower buds are used as wound healing agents. Heals wounds, burns, abrasions, rheumatism and removes warts.

- Poultices for the treatment of skin diseases, removal of warts, treatment of neurodermatitis, eczema, burns, wounds and abrasions, treatment of rheumatism. To prepare them, fresh leaves are crushed and boiled, wrapped in cheesecloth and applied to inflamed areas.

\section{Internal:}

- Decoction from the Caltha palustris. Pour 1 teaspoon of crushed roots with 1 cup of boiling water, then bring to low heat and bring to a boil. Simmer on low heat for 10 minutes, cool and strain. Take the decoction 3 times a day for 1 tablespoon after meals in violation of metabolism, anemia and colds. 1 teaspoon taken with bronchitis, whooping cough, painful menstruation. Decoction has weak antitumor properties.

- Decoction from leaves. 1 teaspoon of the leaves is poured with a glass of boiling water, boiled for 15 minutes in a water bath, cooled for 45 minutes, filtered and boiled with water and brought to initial volume.

- Infusion. Take 1 teaspoon of crushed herbs and pour a glass of boiling water, wrap and infuse for 40 minutes. Take $1 / 3$ cup 3 times a day while eating. Treats whooping cough, bronchial catarrh, painful menstruation.

- Decoction from the whole plant of the Caltha palustris. Pour half a teaspoon of shredded raw material with a glass of boiling water; simmer for 5 minutes over low heat. After that, cool and strain. It is necessary to take $50 \mathrm{ml} 3$ times a day 30 minutes before meals in case of metabolic disorders, anemia, diathesis, colds, fever and as an anti-cingulate agent [23].

\section{Patents}

Quite often, Caltha palustris is used in oriental medicines. It is used in complex drugs of different spectrum of action. The data are presented in Table 1 [31].

Table 1

Drugs of oriental medicine based on Caltha palustris

\begin{tabular}{|c|c|c|c|c|c|}
\hline No. & Name & Author & Country & Patent number & Application \\
\hline 1 & 2 & 3 & 4 & 5 & 6 \\
\hline 1. & $\begin{array}{l}\text { Chinese drug for the } \\
\text { treatment of burns }\end{array}$ & Liu, Baning & China & $\begin{array}{c}\text { CN104288359 A } \\
2015-01-21\end{array}$ & $\begin{array}{l}\text { Astringent, anti- } \\
\text { inflammatory, to promote } \\
\text { wound healing, reduce exu- } \\
\text { dation and edema, pain relief, } \\
\text { reduces blistering, prevent } \\
\text { infectious manifestations. }\end{array}$ \\
\hline 2. & $\begin{array}{l}\text { Skin whitening cosmet- } \\
\text { ics containing specific } \\
\text { herbal extracts or their } \\
\text { alkaline treatment } \\
\text { products }\end{array}$ & $\begin{array}{l}\text { Tachikawa, } \\
\text { Makoto }\end{array}$ & Japan & $\begin{array}{c}\text { JP2001206819 A } \\
2001-07-31\end{array}$ & $\begin{array}{l}\text { The cosmetic agent effec- } \\
\text { tively inhibits the produc- } \\
\text { tion of melanin, whitens the } \\
\text { skin and facilitates age-old } \\
\text { plaque and freckles. }\end{array}$ \\
\hline 3. & $\begin{array}{l}\text { Chinese drug composi- } \\
\text { tion for the treatment of } \\
\text { prostatosis }\end{array}$ & Huang, Xing & China & $\begin{array}{c}\text { CN1341427 A 2002- } \\
\text { 03-27 }\end{array}$ & $\begin{array}{l}\text { It can be used to treat pros- } \\
\text { tatitis, prostate hyperplasia, } \\
\text { orchitis, epididymitis, ure- } \\
\text { thritis, genital herpes, oligu- } \\
\text { ria, hydronephrosis and } \\
\text { cystitis. }\end{array}$ \\
\hline 4. & $\begin{array}{l}\text { Oral care product to } \\
\text { improve tartar removal } \\
\text { by ultrasound. }\end{array}$ & $\begin{array}{l}\text { Hu, Xiaokun; } \\
\text { Liu, Mei; Qin, } \\
\text { Tianmu }\end{array}$ & China & $\begin{array}{c}\text { CN109381385 A } \\
2019-02-26\end{array}$ & $\begin{array}{l}\text { Helps to remove tartar by } \\
\text { low power ultrasound, } \\
\text { which prevents bleeding } \\
\text { and infection. }\end{array}$ \\
\hline 5. & $\begin{array}{l}\text { Non-toxic spray for the } \\
\text { treatment of burns and } \\
\text { technology of its prepa- } \\
\text { ration }\end{array}$ & $\begin{array}{l}\text { Huang, Hain- } \\
\text { ing; Tang, } \\
\text { Hongquan; } \\
\text { Xu, Wenbing; } \\
\text { Wang, Jianjun }\end{array}$ & China & $\begin{array}{c}\text { CN107281303 A } \\
2017-10-24\end{array}$ & $\begin{array}{l}\text { Effectively relieves pain in } \\
\text { burns, accelerates the heal- } \\
\text { ing of the affected areas, } \\
\text { has a bactericidal effect. }\end{array}$ \\
\hline
\end{tabular}


Continuation of Table 1

\begin{tabular}{|c|c|c|c|c|c|}
\hline 1 & 2 & 3 & 4 & 5 & 6 \\
\hline 6. & $\begin{array}{l}\text { Preparation of Chinese } \\
\text { medicinal ointment for } \\
\text { the treatment of burns } \\
\text { and scalp }\end{array}$ & & China & $\begin{array}{c}\text { CN105125769 A } \\
2015-12-09\end{array}$ & $\begin{array}{l}\text { Improves wound healing, } \\
\text { improves blood circulation } \\
\text { and reduces swelling. It is } \\
\text { used for the treatment of } \\
\text { burns. }\end{array}$ \\
\hline 7. & $\begin{array}{l}\text { Chinese medicinal } \\
\text { composition for the } \\
\text { treatment of lumbar } \\
\text { vertebral disorders. }\end{array}$ & $\begin{array}{l}\text { Zhang, } \\
\text { Zhongjian }\end{array}$ & China & $\begin{array}{c}\text { CN103263621 A } \\
2013-08-28\end{array}$ & $\begin{array}{l}\text { Promotes circulation and } \\
\text { elimination of stagnation of } \\
\text { blood, warming of chan- } \\
\text { nels. It can be used to treat } \\
\text { lumbar hyperosteogeny, } \\
\text { lumbar intervertebral disc } \\
\text { prolapse, lumbar muscle } \\
\text { tension, and rheumatic or } \\
\text { rheumatoid lumbar without } \\
\text { side effects. }\end{array}$ \\
\hline 8. & $\begin{array}{l}\text { Drug used in acute } \\
\text { gouty arthritis and } \\
\text { method of its use }\end{array}$ & Zhang, Lizhu & China & $\begin{array}{c}\text { CN103585604 A } \\
2014-02-19\end{array}$ & $\begin{array}{l}\text { Improves blood circulation, } \\
\text { eliminates stagnation, pro- } \\
\text { motes absorption of hard- } \\
\text { ness, eliminates swelling } \\
\text { and reduces pain. Applies } \\
\text { directly to the area of swell- } \\
\text { ing and pain, instantly feel- } \\
\text { ing the cooling effect. }\end{array}$ \\
\hline 9. & $\begin{array}{l}\text { The composition of } \\
\text { traditional Chinese } \\
\text { medicine for the treat- } \\
\text { ment of hyperplasia of } \\
\text { the breast }\end{array}$ & $\begin{array}{c}\text { Dai, Huaying; } \\
\text { Bi, Jianyao; } \\
\text { Yang, Pengfei; } \\
\text { Yu, } \\
\text { Hongqiang; } \\
\text { Liu, Rong }\end{array}$ & China & $\begin{array}{c}\text { CN105770751 A } \\
2016-07-20\end{array}$ & $\begin{array}{l}\text { Promotes blood circulation, } \\
\text { softening and resorption of } \\
\text { solid mass, improvement of } \\
\text { immunity, equilibration of } \\
\text { the endocrine system for } \\
\text { the treatment of various } \\
\text { types of lobular hyperplasia } \\
\text { of the breast. }\end{array}$ \\
\hline
\end{tabular}

\section{Toxicity and contraindications.}

The toxicity of Caltha palustris is caused by the presence of a protoaneminin in a fresh plant. However, according to the literature, they are destroyed in heat treatment [9].

Fresh juice of the aerial part of the plant, collected in the period before flowering, can cause damage to the skin, namely blisters. Excessive intake of infusions or Caltha palustris teas causes pain in the stomach, nausea, vomiting, diarrhoea and allergic reactions [32].

\section{Conclusions}

Based on the results of the study and analysing the literature on the distribution, content of biologically active substances in the aerial part of Caltha palustris, the main aspects of its use in medicine and pharmacy, we can conclude that Caltha palustris is a promising medicinal plant of the Ranunculaceae family. The results of the work testify to the prospects of using Caltha palustris as a medicinal raw material for further thorough research, since the plant has long experience in ethnomedicine use and contains valuable biologically active compounds.

\section{References}

1. Bhandari, P., Rastogi, R. P. (1984). Two nor-triterpene lactones from Caltha palustris. Phytochemistry, 23 (8), 1699-1702. doi: http://doi.org/10.1016/s0031-9422(00)83472-x

2. Bhandari, P., Gray, A., Rastogi, R. (1987). Triterpenoid Saponins fromCaltha palustris. Planta Medica, 53 (1), 98-100. doi: http://doi.org/10.1055/s-2006-962634

3. Bhandari, P., Rastogi, R. P. (1984). Triterpene constituents of Caltha palustris. Phytochemistry, 23 (9), $2082-2085$. doi: http://doi.org/10.1016/s0031-9422(00)84984-5

4. Jurgens, A., Dotterl, S. (2004). Chemical composition of anther volatiles in Ranunculaceae: genera-specific profiles in Anemone, Aquilegia, Caltha, Pulsatilla, Ranunculus, and Trollius species. American Journal of Botany, 91 (12), $1969-1980$. doi: http://doi.org/10.3732/ajb.91.12.1969

5. Suszko, A., Obmińska-Mrukowicz, B. (2013). Influence of polysaccharide fractions isolated from Caltha palustris L. on the cellular immune response in collagen-induced arthritis (CIA) in mice. A comparison with methotrexate. Journal of Ethnopharmacology, 145 (1), 109-117. doi: http://doi.org/10.1016/j.jep.2012.10.038

6. Bruni, A., Bonora, A., Dall'Olio, G. (1986). Protoanemonin Detection in Caltha palustris. Journal of Natural Products, 49 (6), 1172-1173. doi: http://doi.org/10.1021/np50048a058

7. Mubashir, S., Dar, M. Y., Lone, B. A., Zargar, M. I., Shah, W. A. (2014). Anthelmintic, antimicrobial, antioxidant and cytotoxic activity of Caltha palustris var. alba Kashmir, India. Chinese Journal of Natural Medicines, 12 (8), 567-572. doi: http://doi.org/10.1016/s1875-5364(14)60087-x 
8. Agnieszka, S., Bozena, O.-M. (2017). Effects of polysaccharide fractions isolated from Caltha palustris L. on the activity of phagocytic cells \& humoral immune response in mice with collagen-induced arthritis: A comparison with methotrexate. Indian Journal of Medical Research, 145 (2), 229-236.

9. Hrodzinskyi, A. M. (Ed.) (1989). Likarski roslyny. Kyiv: URE, 480-481.

10. Ostapko, V. M. (Ed.) (2010). Chervona knyha Donetskoi oblasti: Roslynnyi svit. Donetsk: «Nova pechat», 58.

11. Kaliuzhnytsia bolotna (Caltha palustris). Available at: http://fitoapteka.org/herbs-k/1073-caltha-palustris

12. Kurenkova, E. M., Starodubtseva, A. M. (2018). Iadovitye rasteniia senokosov i pastbisch lesnoy zony evropeyskoy chasti Rossii: semeystvo Ranunculaceae. Kormoproizvodstvo, 6. Available at: http://kormoproizvodstvo.ru/6-2018/06-2018-03-02-1201/

13. Cieślak, E., Ilnicki, T., Flis, M. (2000). Tsytotaksonomichni doslidzhennia kompleksu Caltha palustris (Ranunculaceae) u Polshchi. Poperednii zvit. Acta Biologica Cracoviensia. Series Botanica, 42 (1), 121-129.

14. Didukh, Ya. P. (Ed.) (2004). Ekoflora Ukrainy. Vol. 2. Kyiv: Fitosotsiotsentr, 480.

15. Нестерук, Ю. (2003). Чорногора. Львів: БаК, 122-123.

16. Ukrainian Biodiversity Information Network. Available at: http://www.ukrbin.com/

17. Wijnands, D. O. (1994). The double-flowered Caltha palustris. Euphytica, 73 (3), 225-239. doi: http://doi.org/10.1007/ bf00036702

18. Samura, B. A. (Ed.) (2003). Fitoterapiia v klinike vnutrennih bolezney. Harkov: Izd-vo NFaU: Zolotye stranitsy, 416.

19. Sokolov, P. D. (1994). Rastitelnye resursy. Sankt-Peterburg: Nauka, 112.

20. Orlov, B. N., Gelashvili, D. B., Ibragimov, A. K. (1990). IAdovitye zhivotnye i rasteniia SSSR. Moscow: Vysshaia shkola, 226-227.

21. Martynov, A. M., Dul, V. N., Dargaeva, T. D., Chuparina, E. V. (2017). Izuchenie himicheskogo sostava travy kaluzhnitsy bolotnoy (Caltha palustris ). Voprosy obespecheniia kachestva lekarstvennyh sredstv, 4 (18), 66-71.

22. Rastitelnye resursy SSSR. TSvetkovye rasteniia, ih himicheskiy sostav, ispolzovanie; Semeystva Magnoliaceae Limoniaceae (1984). Leningrad: Nauka, 55-57.

23. Kaliuzhnytsia bolotna, likarski vlastyvosti, otruinist ta protypokazannia (2019). Available at: https://toxicplants.pp.ua/index.php/otrujni-roslini/rodyna-zhovtetsevi/606-kalyuzhnitsya-bolotna-likarski-vlastivosti-otrujnist-ta-protipokazannya

24. Bonora, A., Tosi, B., Donini, A., Botta, B., Bruni, A. (1987). Elicitor-induced Accumulation of Protoanemonin in Caltha palustris L. Journal of Plant Physiology, 131 (5), 489-494. doi: http://doi.org/10.1016/s0176-1617(87)80291-2

25. Entsiklopedicheskiy slovar F. A. Brokgauza i I. A. Efrona (1890-1907). Saint Petersburg: Brokgauz-Efron.

26. Preobrazhenskiy, N. A., Genkin, E. I. (1953). Himiia organicheskih lekarstvennih veschestv. Moscow: Leningrad: GOSKHIMIZDAT, 595.

27. Formanchuk, K. V. (Ed.) (2007). Roslyny daruiut zdorovia: Fitoterapevtychnyi entsyklopedychnyi dovidnyk. Lviv; Avers, 568 .

28. Pnevskyi, V. (2016). Zolotysta kaima vesny. Lisovyi visnyk, 4 (55). Available at: https://lisvisnyk.com.ua/\%D0\%B7\%D0\% BE\%D0\%BB\%D0\%BE\%D1\%82\%D0\%B8\%D1\%81\%D1\%82\%D0\%B0-\%D0\%BA\%D0\%B0\%D0\%B9\%D0\%BC\%D0\%B0-\%D0\% $\mathrm{B} 2 \% \mathrm{D} 0 \% \mathrm{~B} 5 \% \mathrm{D} 1 \% 81 \% \mathrm{D} 0 \% \mathrm{BD} \% \mathrm{D} 0 \% \mathrm{~B} 8 /$

29. Halium-Kheel - instruktsiia, pokazannia, sklad, sposib zastosuvannia. Available at: https://tabletki.ua/uk/

30. Washington HomeopathicProducts. Available at: http://www.homeopathyworks.com

31. European Patent Office. Available at: https://worldwide.espacenet.com/

32. Yelin, Yu. Ya., Zerova, M. Ya., Lushpa, V. I., Shabrova, S. I. (1983). Dary lisiv. Kyiv: Urozhai, 437.

Received date 12.03.2020

Accepted date 08.04.2020

Published date 30.04.2020

Viktiriia Liakh, Postgraduate Student, Department of Technology of Biologically Active Substances, Pharmacy and Biotechnology, Lviv Polytechnic National University, St. Bandery str., 12, Lviv, Ukraine, 79013

E-mail: lyah.vicka1@gmail.com

Roksolana Konechna, PhD, Associate Professor, Department of Technology of Biologically Active Substances, Pharmacy and Biotechnology, Lviv Polytechnic National University, St. Bandery str., 12, Lviv, Ukraine, 79013 E-mail: rkonechna@ukr.net

Mylyanych Andriy, PhD, Associate Professor, Department of Technology of Biologically Active Substances, Pharmacy and Biotechnology, Lviv Polytechnic National University, St. Bandery str., 12, Lviv, Ukraine, 79013 E-mail: anry72@meta.ua

Lesia Zhurakhivska, $\mathrm{PhD}$, Associate Professor, Department of Technology of Biologically Active Substances, Pharmacy and Biotechnology, Lviv Polytechnic National University, St. Bandery str., 12, Lviv, Ukraine, 79013 E-mail: zhurakhivska@ukr.net

Iryna Hubytska, PhD, Associate Professor, Department of Technology of Biologically Active Substances, Pharmacy and Biotechnology, Lviv Polytechnic National University, St. Bandery str., 12, Lviv, Ukraine, 79013 E-mail: ihubytska@gmail.com

Volodymyr Novikov, Doctor of Chemical Sciences, Professor, Department of Technology of Biologically Active Substances, Pharmacy and Biotechnology, Lviv Polytechnic National University, St. Bandery str., 12, Lviv, Ukraine, 79013

E-mail: volodymyr.p.novikov@1pnu.ua 